\title{
Inhibition of Collagen Related Peptide Induced Platelet Activation and Apoptosis by Ceritinib
}

\author{
Hang Cao Anja T. Umbach ${ }^{a}$ Rosi Bissingera Meinrad Gawaz ${ }^{\mathrm{a}}$ Florian Lang ${ }^{\mathrm{b}, \mathrm{c}}$ \\ aDepartment of Internal Medicine III and 'bepartment of Physiology, Eberhard-Karls-University, \\ Tübingen, Germany; 'Department of Molecular Medicine II, Medical Faculty, Heinrich Heine University \\ Düsseldorf, Germany
}

\section{Key Words}

$\mathrm{CRP} \cdot$ Orai1 $\cdot$ Cytosolic $\mathrm{Ca}^{2+}$ concentration $\cdot$ Oxidative stress $•$ Platelet activation $\cdot$ Degranulation - Integrin $\bullet$ Caspase $\bullet$ Phosphatidylserine translocation • Cell volume

\begin{abstract}
Background/Aims: The anaplastic lymphoma (tyrosine) kinase (ALK) inhibitor ceritinib triggers apoptosis of tumor cells and eryptosis of erythrocytes. Blood platelets may similarly enter a state resembling apoptosis, which could be triggered by activation with collagen related peptide (CRP). CRP-induced platelet apoptosis is characterized by cell membrane scrambling with phosphatidylserine exposure to the platelet surface and cell shrinkage, preceded by externalization of $\mathrm{Ca}^{2+}$ channel Orai1, increase of cytosolic $\mathrm{Ca}^{2+}$-activity $\left(\left[\mathrm{Ca}^{2+}\right]_{\mathrm{i}}\right)$, formation of reactive oxygen species (ROS), and caspase activation. The present study explored whether ceritinib triggers platelet apoptosis and/or modifies the CRP induced apoptosis. Methods: Platelets isolated from wild-type mice were exposed for 30 minutes to ceritinib $(1.5 \mu \mathrm{g} / \mathrm{ml})$ without or with $2.5-15 \mathrm{~min}$ pretreatment with CRP $(2 \mu \mathrm{g} / \mathrm{ml}$ or $5 \mu \mathrm{g} / \mathrm{ml})$. Flow cytometry was employed to estimate cytosolic $\mathrm{Ca}^{2+}$-activity $\left(\left[\mathrm{Ca}^{2+}\right]_{i}\right)$ from Fluo-3 fluorescence, ROS abundance from 2',7'-dichlorodihydrofluorescein diacetate fluorescence, platelet degranulation from P-selectin abundance, integrin activation from $\alpha_{\text {IIb }} \beta_{3}$ integrin abundance, caspase activity utilizing an Active Caspase-3 Staining kit, phosphatidylserine abundance from annexin-V-binding, platelet volume from forward scatter and aggregation utilizing staining with CD9-APC and CD9PE. Results: In the absence of CRP, ceritinib slightly, but significantly decreased $\left[\mathrm{Ca}^{2+}\right]_{i}$ without significantly modifying the other measured parameters. CRP significantly increased $\left[\mathrm{Ca}^{2+}\right]_{i^{\prime}}$ ROS abundance, $P$-selectin abundance, activated $\alpha_{\mathrm{Ib}} \beta_{3}$ integrin, annexin-V-binding, caspase activity as well as aggregation and decreased cell volume, all effects significantly blunted in the presence of ceritinib. Conclusions: The present observations uncover a novel, unexpected effect of ceritinib, i.e. inhibition of CRP-induced platelet activation and apoptosis.
\end{abstract}




\section{Cellular Physiology Cell Physiol Biochem 2018:45:1707-1716

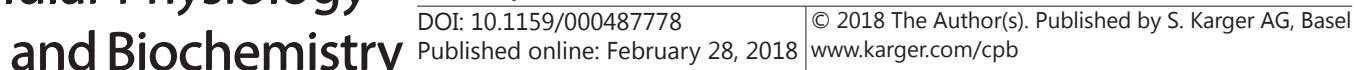 \\ Cao et al.: Ceritinib Sensitive Platelet Function}

\section{Introduction}

The anaplastic lymphoma (tyrosine) kinase (ALK) inhibitor ceritinib is effective in the treatment of ALK positive non-small cell lung carcinoma [1-15]. Ceritinib has been shown to trigger apoptosis of tumor cells [16] and eryptosis, the suicidal erythrocyte death [17].

Blood platelets may similarly enter apoptosis, which is characterized by caspase activation, cell shrinkage, and cell membrane scrambling with phosphatidylserine translocation to the cell surface $[18,19]$. Platelet apoptosis may be preceded by platelet activation leading to hemostasis and/or thrombotic occlusion [20, 21]. Activated platelets are involved in the pathophysiology of arterial thrombosis, vascular inflammation and atherogenesis $[21,22]$. Platelets are activated by an increase of cytosolic $\mathrm{Ca}^{2+}$ concentration $\left(\left[\mathrm{Ca}^{2+}\right]_{\mathrm{i}}\right)[23]$, due to $\mathrm{Ca}^{2+}$ release from intracellular stores [24] and subsequent entry of $\mathrm{Ca}^{2+}$ through $\mathrm{Ca}^{2+}$ release-activated channel Orai1 in the plasma membrane [23, 25-27]. Platelet activity and apoptosis could be triggered by collagen related peptide [28].

To the best of our knowledge, nothing is known about an effect of ceritinib on platelet function and survival.

The present study thus explored whether ceritinib influences platelet activity and apoptosis without and with additional stimulation by collagen related peptide (CRP). Surprisingly, ceritinib decreased $\left[\mathrm{Ca}^{2+}\right]_{\mathrm{i}}$, virtually abrogated the effect of CRP on $\left[\mathrm{Ca}^{2+}\right]_{\mathrm{i}^{\prime}}$, and significantly blunted the effect of CRP on platelet activity and apoptosis.

\section{Materials and Methods}

Mice

All animal experiments were conducted according to the German law for the welfare of animals and were approved by the authorities of the state of Baden-Württemberg. Experiments were performed with blood platelets isolated from wild type mice. The mice had free access to water and control chow (Ssniff, Soest, Germany).

\section{Preparation of mouse platelets}

Platelets were obtained from 10 - to 12 -week-old mice of either sex. The mice were anesthetized and $800 \mu \mathrm{l}$ blood was drawn from the retro-orbital plexus into tubes with $200 \mu$ l acid-citrate-dextrose buffer before the mice were sacrificed [29]. Platelet rich plasma (PRP) was obtained by centrifugation at $260 \mathrm{~g}$ for 5 minutes. Afterwards, PRP was centrifuged at $640 \mathrm{~g}$ for 5 minutes to pellet the platelets. Where necessary, apyrase $\left(0.02 \mathrm{U} / \mathrm{ml}\right.$; Sigma-Aldrich) and prostaglandin $\mathrm{I}_{2}(0.5 \mu \mathrm{M}$; Calbiochem) were added to the PRP to prevent activation of platelets during isolation [30]. After two washing steps, the pellet of washed platelets was re-suspended in modified Tyrode-HEPES buffer ( $\mathrm{pH} 7.4$, supplemented with $1 \mathrm{mM} \mathrm{CaCl}_{2}$ ). Where indicated, collagen related peptide (kindly provided by R. Farndale, University of Cambridge, Cambridge, UK) was added at the indicated concentrations [31].

\section{Orai1 abundance at platelet surface}

Orai1 surface expression was quantified in platelets by flow cytometry. Washed platelets were incubated for $60 \mathrm{~min}\left(37^{\circ} \mathrm{C}\right)$ with Orai1 rabbit anti-mouse antibody (Abcam), washed once in Tyrode buffer, and stained in 1:250 diluted $\mathrm{CF}^{\mathrm{TM}} 488 \mathrm{~A}$-labelled anti-rabbit secondary antibody (Sigma-Aldrich) for $30 \mathrm{~min}\left(37^{\circ} \mathrm{C}\right.$ ). Samples were immediately analyzed on a FACS Calibur flow cytometer (BD Biosciences).

\section{Cytosolic calcium}

For the measurement of the cytosolic $\mathrm{Ca}^{2+}$ concentration the platelet preparation was washed once in Tyrode buffer ( $\mathrm{pH} 7.4$ ), stained with $3 \mu \mathrm{M}$ Fluo-3AM (Biotinium, USA) in the same buffer and incubated at $37^{\circ} \mathrm{C}$ for 30 minutes. Following the indicated experimental treatment, relative fluorescence was measured utilizing a BD FACS Calibur (BD Biosciences, Heidelberg, Germany) [32]. 


\section{Cellular Physiology Cell Physiol Biochem 2018:45:1707-1716

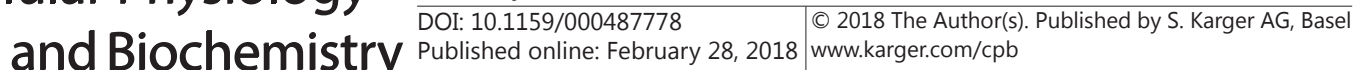 \\ Cao et al.: Ceritinib Sensitive Platelet Function}

Reactive oxygen species (ROS)

The abundance of ROS was determined utilizing 2',7'-dichlorodihydrofluorescein diacetate (DCFDA). Washed platelets were stained with DCFDA (10 $\mu$ M; Sigma, Schnelldorf, Germany) in Tyrode buffer at $37^{\circ} \mathrm{C}$ for $30 \mathrm{~min}$ and washed once in Tyrode buffer. The DCFDA-loaded platelets were re-suspended in $200 \mu \mathrm{l}$ Tyrode buffer and ROS-dependent fluorescence intensity was measured at an excitation wavelength of 488 $\mathrm{nm}$ and an emission wavelength of $530 \mathrm{~nm}$ on a BD FACS Calibur.

\section{P-selectin and activated integrin abundance}

Fluorophore-labeled antibodies were utilized for the detection of P-selectin expression (Wug.E9-FITC) [33] and the active form of $\alpha_{\mathrm{IIb}} \beta_{3}$ integrin (JON/A-PE) [34]. Washed mouse platelets $\left(1 \times 10^{6}\right)$ were suspended in modified Tyrode buffer ( $\mathrm{pH} 7.4$ ) containing $1 \mathrm{mM} \mathrm{CaCl}_{2}$ and antibodies (1:10 dilution) and subsequently subjected to the respective treatments and for the indicated time periods at room temperature (RT). The reaction was stopped by addition of PBS and the samples were immediately analyzed on a BD FACSCalibur.

Phosphatidylserine exposure and forward scatter

Phosphatidylserine exposure was determined in platelets with and without 10 minutes CRP treatment. To this end, the platelet preparation was centrifuged at $660 \mathrm{~g}$ for 5 minutes followed by washing once with Tyrode buffer ( $\mathrm{pH} 7.4$ ) with $1 \mathrm{mM} \mathrm{CaCl}_{2}$, staining with 1:20 dilution of Annexin-V FITC (Mabtag, Germany) in Tyrode buffer ( $\mathrm{pH} 7.4$ ) with $2 \mathrm{mM} \mathrm{CaCl}_{2}$ and incubation at $37^{\circ} \mathrm{C}$ for 30 minutes. Annexin-V binding reflecting surface exposure of phosphatidylserine was evaluated by flow cytometry utilizing a BD FACSCalibur. In parallel, the forward scatter (FSC) of the platelets was determined by flow cytometry as a measure of platelet size $[28,35]$.

Caspase-3 activity

Caspase 3 activity was determined utilizing a CaspGlow Fluorescein Active Caspase-3 Staining kit from BioVision (CA, USA) according to the manufacturer's instruction. Fluorescence intensity was measured at an excitation wavelength of $488 \mathrm{~nm}$ and an emission wavelength of 530 in a BD FACSCalibur (BD Biosciences, USA).

\section{Platelet aggregation}

Platelet aggregation was determined utilizing flow cytometry as previously described [36]. To this end platelets were labeled with CD9-APC and CD9-PE monoclonal antibodies (1:100 dilution, Abcam) for 15 minutes at room temperature. Following incubation, differently labeled samples were washed twice, mixed 1:1, and incubated in $1.5 \mu \mathrm{g} / \mathrm{ml}$ ceritinib (Medchem Express) for $30 \mathrm{~min}$ at $37^{\circ} \mathrm{C}$ while shaking at $600 \mathrm{rpm}$ for 10 minutes. Pre-incubated platelets were activated with $2 \mu \mathrm{g} / \mathrm{ml} \mathrm{CRP}$ at $37^{\circ} \mathrm{C}$, while shaking at $1000 \mathrm{rpm}$. At the indicated time points, samples were fixed by addition of $0.5 \%$ paraformaldehyde (Carl Roth, Germany) in phosphate-buffered saline. The fixed samples were measured utilizing a BD FACSCalibur (BD Biosciences, Heidelberg, Germany). For quantification, a quadrant was set in the dot plot of respective channels on non-stimulated platelets. The appearance of double-colored events in the upper right quadrant (Q2) was quantified as percentage of total amount of labeled events $(\mathrm{Q} 1+\mathrm{Q} 2+\mathrm{Q} 4)$ at every time point analyzed.

\section{Statistical analysis}

Data are provided as means $\pm \mathrm{SEM} ; n$ represents the number of independent experiments. All data were tested for significance using ANOVA with Tukey's test as post-test or unpaired student's t-test as appropriate. Results with $p<0.05$ were considered statistically significant.

\section{Results}

The present study explored whether ceritinib triggers and/or modifies CRP-induced activation and apoptosis of blood platelets. To this end, murine platelets were isolated from wild type mice and incubated for $30 \mathrm{~min}$ in the absence or presence of ceritinib $(1.5 \mu \mathrm{g} / \mathrm{ml})$ and without or with subsequent exposure to $2 \mu \mathrm{g} / \mathrm{ml}$ or $5 \mu \mathrm{g} / \mathrm{ml}$ collagen related peptide (CRP). The platelets were subsequently analyzed utilizing flow cytometry. 

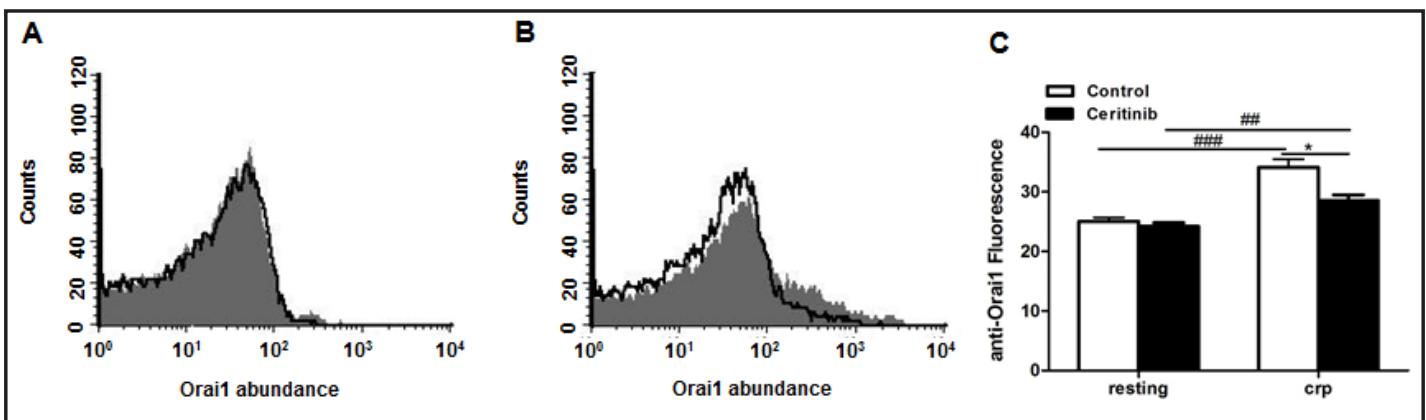

Fig. 1. Ceritinib sensitive CRP-induced increase of Orai1 abundance. A,B. Original histograms of Orai1 abundance at the surface of murine platelets without (A) and with (B) a 15 min treatment with collagen related peptide (CRP, $2 \mu \mathrm{g} / \mathrm{ml}$ ) without (grey areas) and with (black lines) presence of ceritinib $(1.5 \mu \mathrm{g} / \mathrm{ml}$, $30 \mathrm{~min})$. C. Arithmetic means \pm SEM $(n=4)$ of Orai1 abundance at the surface of murine platelets without (left bars) and with (right bars) a 15 min CRP treatment in the absence (white bars) and presence (black bars) of $1.5 \mu \mathrm{g} / \mathrm{ml}$ ceritinib. ${ }^{*}(\mathrm{p}<0.05)$ indicates statistically significant difference from absence of ceritinib, $\# \#(p<0.01), \# \# \#(p<0.001)$ indicates statistically significant difference from absence of CRP.

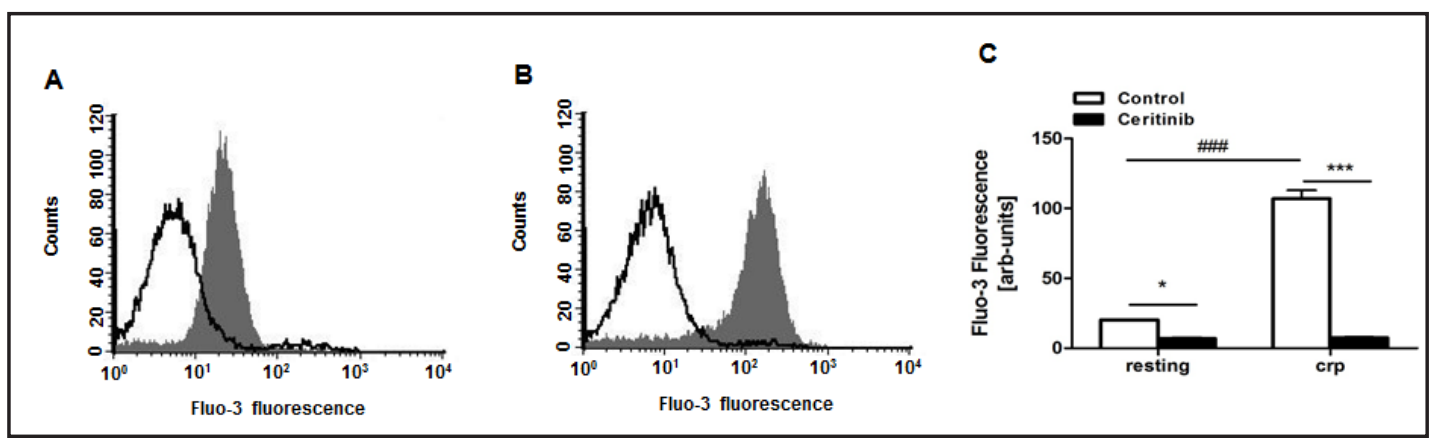

Fig. 2. Ceritinib sensitive CRP-induced increase of cytosolic $\mathrm{Ca}^{2+}$ concentration. A,B. Original histograms of Fluo-3 fluorescence reflecting cytosolic $\mathrm{Ca}^{2+}$ activity in murine platelets without (A) and with (B) a $150 \mathrm{~s}$ treatment with CRP $(2 \mu \mathrm{g} / \mathrm{ml})$ without (grey areas) and with (black lines) presence of ceritinib $(1.5 \mu \mathrm{g} / \mathrm{ml}$, $30 \mathrm{~min})$. C. Arithmetic means \pm SEM $(\mathrm{n}=4)$ of Fluo-3 fluorescence reflecting cytosolic $\mathrm{Ca}^{2+}$ activity in murine platelets without (left bars) and with (right bars) a $150 \mathrm{~s}$ CRP treatment in the absence (white bars) and presence (black bars) of $1.5 \mu \mathrm{g} / \mathrm{ml}$ ceritinib. ${ }^{*}(\mathrm{p}<0.05),{ }^{* * *}(\mathrm{p}<0.001)$ indicates statistically significant difference from absence of ceritinib, \#\#\#(p<0.001) indicates statistically significant difference from absence of CRP.

Orai1 protein abundance was quantified utilizing fluorescent antibodies. As illustrated in Fig. 1A-C, in the absence of CRP ceritinib did not significantly modify Orai1 abundance at the platelet surface. CRP treatment significantly increased Orai1 protein abundance at the platelet surface, an effect significantly blunted in the presence of ceritinib.

Fluo-3 fluorescence was employed to estimate cytosolic $\mathrm{Ca}^{2+}$ concentration $\left(\left[\mathrm{Ca}^{2+}\right]_{\mathrm{i}}\right)$. As illustrated in Fig. 2A-C, in the absence of CRP ceritinib significantly decreased $\left[\mathrm{Ca}^{2+}\right]_{\mathrm{i}^{-}}$CRP treatment was followed by a sharp significant increase of $\left[\mathrm{Ca}^{2+}\right]_{i}$, an effect virtually abolished in the presence of ceritinib (Fig. 2A-C).

2',7'-dichlorodihydrofluorescein diacetate (DCFDA) fluorescence was taken as a measure of the reactive oxygen species (ROS) abundance. As illustrated in Fig. 3A-C, ceritinib did not significantly modify ROS abundance in the absence of CRP. Treatment with CRP was followed by a significant increase of ROS abundance, an effect significantly blunted in the presence of ceritinib (Fig. 3A-C).

Platelet degranulation was estimated from increase of P-selectin abundance at the platelet surface, which was determined utilizing specific antibodies and flow cytometry. In the absence of CRP, the P-selectin abundance was negligible at the surface of resting platelets and not 

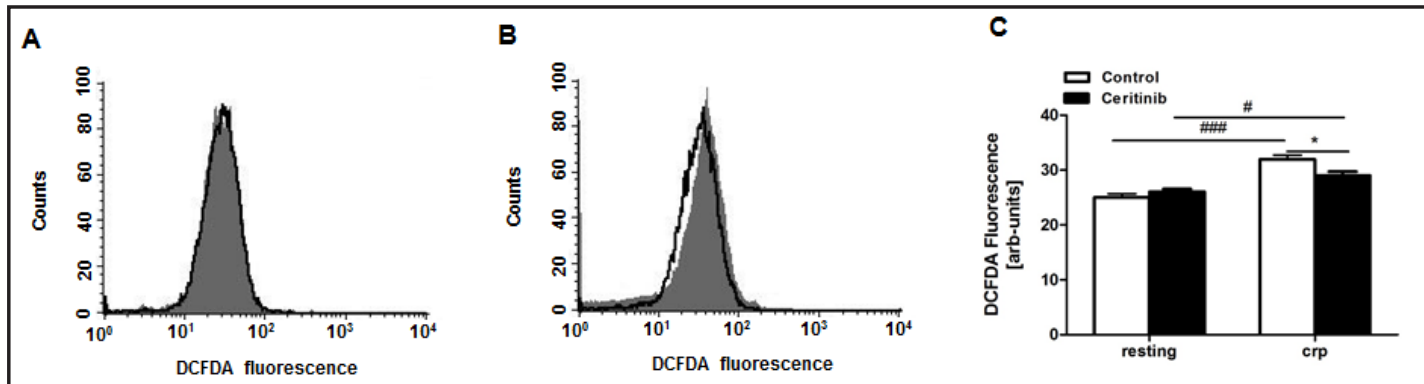

Fig. 3. Ceritinib sensitive CRP-dependent oxidative stress. A,B. Original histograms of 2',7'-dichlorodihydrofluorescein diacetate (DCFDA) fluorescence reflecting abundance of reactive oxygen species (ROS) in murine platelets without (A) and with (B) a 10 min treatment with CRP $(2 \mu \mathrm{g} / \mathrm{ml})$ without (grey areas) and with (black lines) presence of ceritinib $(1.5 \mu \mathrm{g} / \mathrm{ml}, 30 \mathrm{~min})$. C. Arithmetic means \pm SEM $(\mathrm{n}=4)$ of the percentage of annexin-V-binding murine platelets in the absence (white bars) and presence (black bars) of $1.5 \mu \mathrm{g} / \mathrm{ml}$ ceritinib without (left bars) and with (right bars) a $10 \mathrm{~min}$ CRP treatment $(2 \mu \mathrm{g} / \mathrm{ml}) .{ }^{*}(\mathrm{p}<0.05)$ indicates statistically significant difference from absence of ceritinib, $\#(p<0.05)$, \#\#\#(p<0.001) indicates statistically significant difference from absence of CRP.
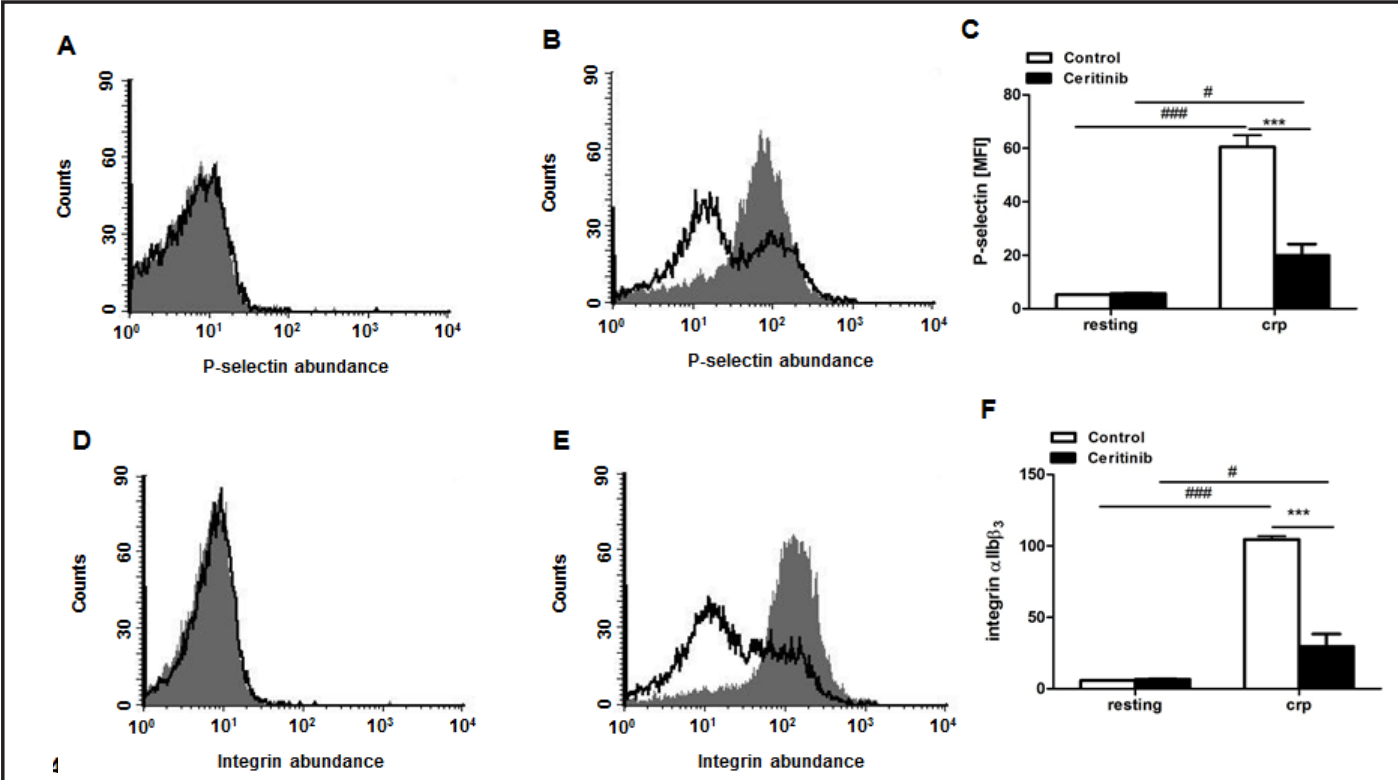

Fig. 4. Ceritinib sensitive CRP-induced platelet degranulation and integrin $\alpha_{\mathrm{IIb}} \beta_{3}$ activation. A,B. Original histograms of P-selectin related fluorescence in murine platelets without (A) and with (B) a 15 min CRP (2 $\mu \mathrm{g} / \mathrm{ml}$ ) treatment without (grey areas) and with (black lines) presence of ceritinib (1.5 $\mu \mathrm{g} / \mathrm{ml}, 30 \mathrm{~min}$ ). C. Arithmetic means \pm SEM ( $n=4)$ of the P-selectin related fluorescence (arbitrary units) in murine platelets without (left bars) and with (right bars) a $15 \mathrm{~min}$ CRP treatment $(2 \mu \mathrm{g} / \mathrm{ml}$ ) in the absence (white bars) and presence (black bars) of $1.5 \mu \mathrm{g} / \mathrm{ml}$ ceritinib. D,E. Original histograms of activated $\alpha_{\mathrm{IIb}} \beta_{3}$ integrin related fluorescence in murine platelets without (D) and with (E) a $15 \mathrm{~min}$ CRP (2 $\mu \mathrm{g} / \mathrm{ml}$ ) treatment without (grey areas) and with (black lines) presence of ceritinib (1.5 $\mu \mathrm{g} / \mathrm{ml}, 30 \mathrm{~min})$. F. Arithmetic means \pm SEM $(\mathrm{n}=4)$ of activated $\alpha_{\mathrm{Ib}} \beta_{3}$ integrin related fluorescence (arbitrary units) in murine platelets without (left bars) and with (right bars) a $15 \mathrm{~min}$ CRP treatment ( $2 \mu \mathrm{g} / \mathrm{ml}$ ) in the absence (white bars) and presence (black bars) of $1.5 \mu \mathrm{g} / \mathrm{ml}$ ceritinib. ${ }^{* *}(\mathrm{p}<0.001)$ indicates statistically significant difference from absence of ceritinib, $\#(p<0.05), \# \# \#(p<0.001)$ indicates statistically significant difference from absence of CRP.

significantly modified by ceritinib treatment. CRP significantly increased P-selectin abundance, an effect significantly blunted in the presence of ceritinib (Fig. 4A-C).

Similarly, in the absence of CRP, the abundance of active integrin $\alpha_{\mathrm{IIb}} \beta_{3}$ was negligible at the platelet surface and not significantly modified by ceritinib treatment (Fig. 4D-F). The 


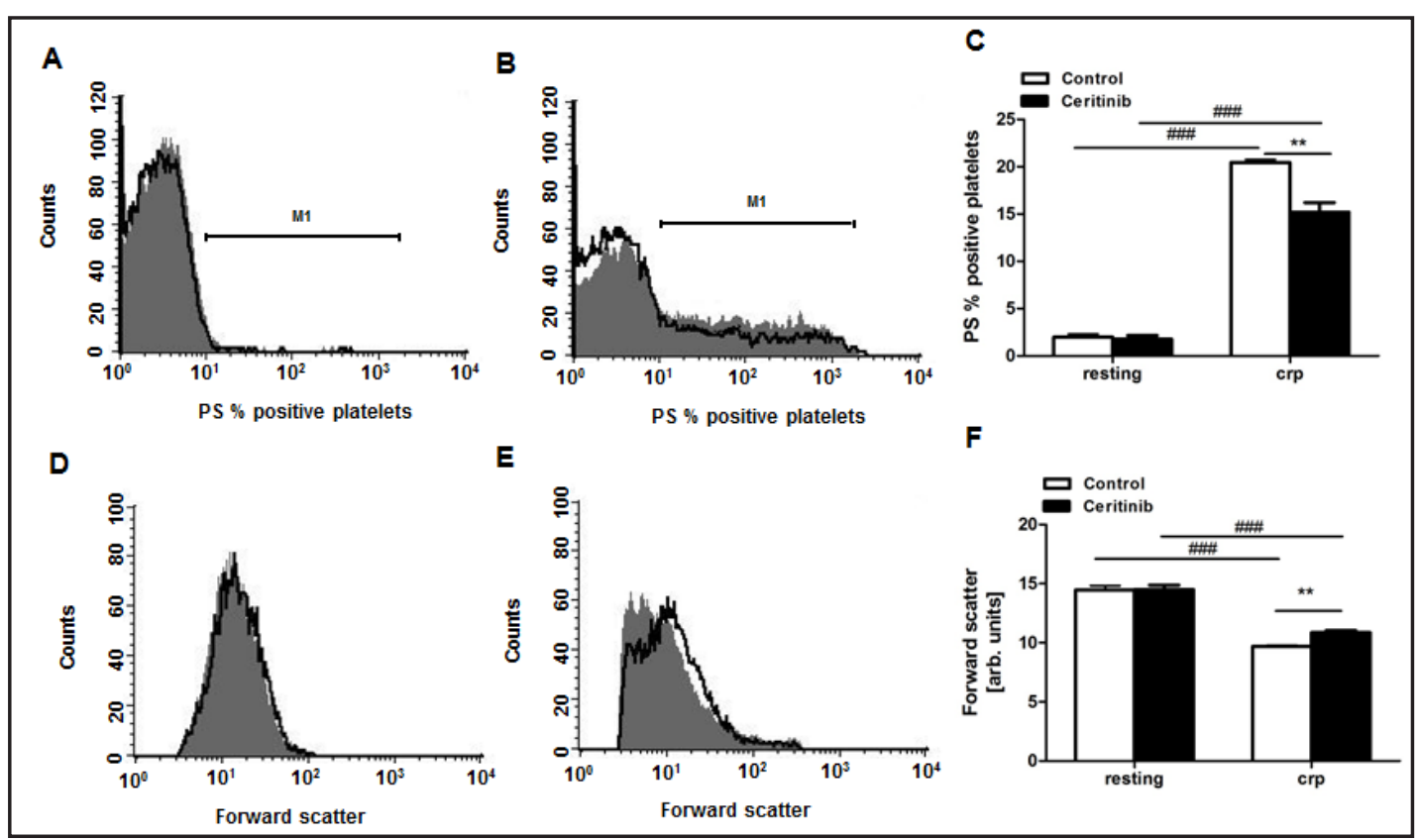

Fig. 5. Ceritinib sensitive CRP-dependent cell membrane scrambling and cell volume. A,B. Original histograms of annexin-V-binding reflecting phosphatidylserine abundance at the surface of murine platelets without (A) and with (B) a 10 min treatment with CRP $(5 \mu \mathrm{g} / \mathrm{ml}$ ) without (grey areas) and with (black lines) presence of ceritinib $(1.5 \mu \mathrm{g} / \mathrm{ml}, 30 \mathrm{~min})$. C. Arithmetic means \pm SEM $(\mathrm{n}=4)$ of the percentage of annexin-V-binding murine platelets in the absence (white bars) and presence (black bars) of $1.5 \mu \mathrm{g} / \mathrm{ml} \mathrm{ce-}$ ritinib without (left bars) and with (right bars) a $10 \mathrm{~min}$ CRP treatment ( $5 \mu \mathrm{g} / \mathrm{ml}$ ). D,E. Original histograms of forward scatter reflecting cell volume of murine platelets without (D) and with (E) a 10 min treatment with CRP ( $5 \mu \mathrm{g} / \mathrm{ml})$ without (grey areas) and with (black lines) presence of ceritinib $(1.5 \mu \mathrm{g} / \mathrm{ml}, 30 \mathrm{~min})$. F. Arithmetic means \pm SEM ( $n=4$ ) of forward scatter reflecting cell volume of murine platelets without (left bars) and with (right bars) a $10 \mathrm{~min}$ CRP treatment $(5 \mu \mathrm{g} / \mathrm{ml})$ in the absence (white bars) and presence (black bars) of $1.5 \mu \mathrm{g} / \mathrm{ml}$ ceritinib. ${ }^{* *}(\mathrm{p}<0.01)$ indicates statistically significant difference from absence of ceritinib, \#\#\#( $\mathrm{p}<0.001)$ indicates statistically significant difference from absence of CRP.

abundance of active integrin $\alpha_{\mathrm{II}} \beta_{3}$ was significantly increased by CRP treatment, an effect again significantly blunted in the presence of ceritinib (Fig 4D-F).

Phosphatidylserine abundance was estimated from annexin-V-binding. As illustrated in Fig. 5A-C, in the absence of CRP the percentage of annexin- $\mathrm{V}$ positive platelets was again negligible, irrespective of the presence of ceritinib. CRP significantly enhanced the percentage of annexin- $\mathrm{V}$ binding platelets, an effect again significantly blunted in the presence of ceritinib (Fig. 5A-C).

Platelet volume was estimated from forward scatter, which was determined by flow cytometry. As illustrated in Fig. 5D-F, without presence of CRP forward scatter was not significantly modified by ceritinib. CRP treatment was followed by a marked decrease of forward scatter, an effect slightly but significantly blunted by ceritinib (Fig. 5D-F).

A kit has been used for the detection of activated caspase 3. As illustrated in Fig. 6A-C, caspase 3 activity was negligible in the absence of CRP, irrespective of the presence of ceritinib. CRP sharply and significantly enhanced caspase activity, an effect again significantly blunted by ceritinib (Fig. 6A-C).

To elucidate the effect of CRP and ceritinib on platelet aggregation, platelets were labeled with two distinct dyes and the coincidence of the two dyes estimated by flow cytometry. As illustrated in Fig. 7, prior to CRP treatment, aggregation of resting platelets was similarly low in absence and presence of ceritinib. CRP treatment significantly increased platelet aggregation, an effect significantly blunted by ceritinib. 


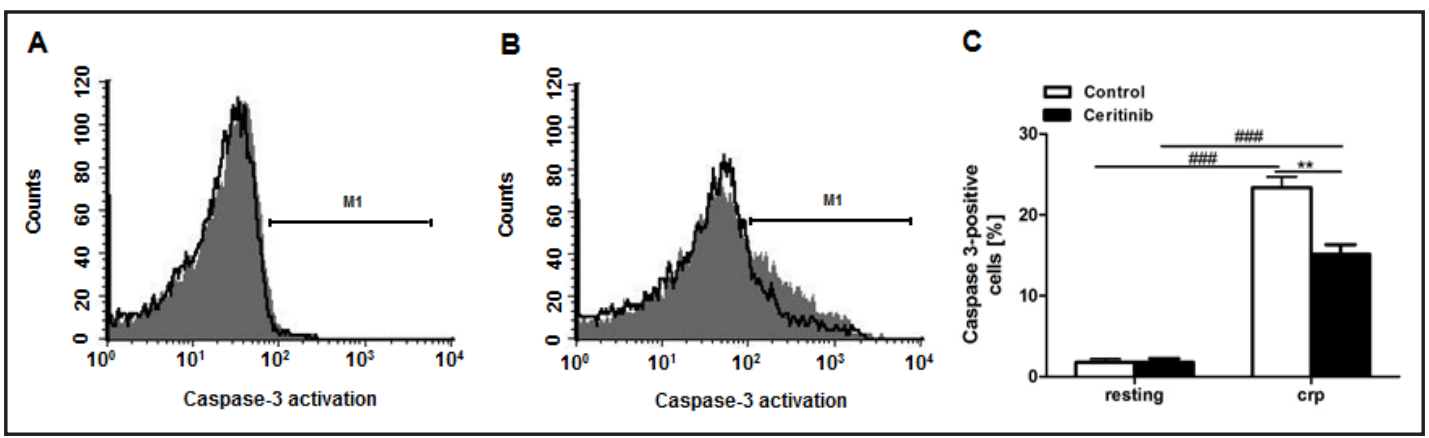

Fig. 6. Ceritinib sensitive CRP-induced increase of caspase-3 activity. A,B. Original histograms of fluorescence reflecting caspase- 3 activity in murine platelets without (A) and with (B) a 10 min treatment with CRP $(5 \mu \mathrm{g} / \mathrm{ml})$ without (grey areas) and with (black lines) presence of ceritinib $(1.5 \mu \mathrm{g} / \mathrm{ml}, 30 \mathrm{~min})$. C. Arithmetic means \pm SEM $(n=4)$ of the percentage of caspase-3 positive murine platelets in the absence (white bars) and presence (black bars) of $1.5 \mu \mathrm{g} / \mathrm{ml}$ ceritinib without (left bars) and with (right bars) a $10 \mathrm{~min}$ CRP treatment $(5 \mu \mathrm{g} / \mathrm{ml}) . * *(\mathrm{p}<0.01)$ indicates statistically significant difference from absence of ceritinib, $\# \# \#(\mathrm{p}<0.001)$ indicates statistically significant difference from absence of CRP.

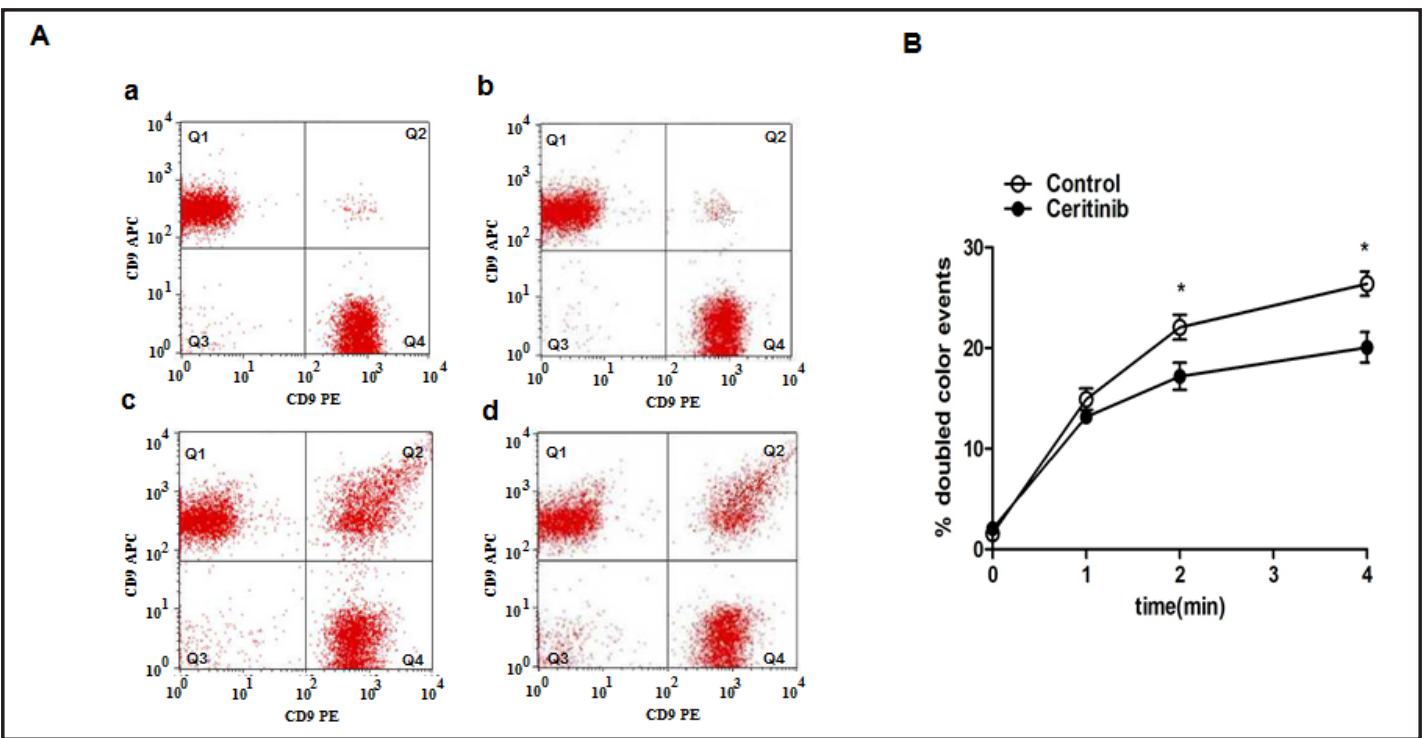

Fig. 7. Ceritinib sensitive CRP-induced platelet aggregation. A. Original dot blots reflecting platelet aggregation without $(\mathrm{a}, \mathrm{c})$ and with $(\mathrm{b}, \mathrm{d})$ prior ceritinib $(1.5 \mu \mathrm{g} / \mathrm{ml})$ treatment, and subsequent treatment with CRP $(2 \mu \mathrm{g} / \mathrm{ml})$ for $0 \mathrm{~min}(\mathrm{a}, \mathrm{b})$ and $4 \mathrm{~min}(\mathrm{c}, \mathrm{d})$. B. Arithmetic means $\pm \operatorname{SEM}(\mathrm{n}=4)$ of platelet aggregation without (white circles) and with (black circles) prior ceritinib $(1.5 \mu \mathrm{g} / \mathrm{ml})$ treatment as a function of time after addition of CRP $(2 \mu \mathrm{g} / \mathrm{ml}) .{ }^{*}(\mathrm{p}<0.05)$ indicates statistically significant difference from absence of ceritinib.

\section{Discussion}

The present study uncovers a completely novel inhibitor of platelet activity and apoptosis. Specifically, it is shown that treatment of murine platelets with ceritinib significantly lowers the cytosolic $\mathrm{Ca}^{2+}$ activity $\left(\left[\mathrm{Ca}^{2+}\right]_{\mathrm{i}}\right)$ and significantly blunts the up-regulating effect of collagen related peptide (CRP) on Orai1 protein abundance at the platelet surface, $\left[\mathrm{Ca}^{2+}\right]_{i}$, P-selectin abundance, $\alpha_{\mathrm{II}} \beta_{3}$ integrin activity, annexin-V-binding, caspase activity, and aggregation. Moreover, ceritinib slightly, but significantly, blunts the CRP-induced platelet shrinkage.

The inhibitory effect of ceritinib on platelet activation and apoptosis is presumably in part due to blunting of the CRP-induced increase of $\left[\mathrm{Ca}^{2+}\right]_{\mathrm{i}}[26,37]$. An increase of $\left[\mathrm{Ca}^{2+}\right]_{i}$ 


\section{Cellular Physiology Cell Physiol Biochem 2018:45:1707-1716 \begin{tabular}{c|c|c|c|} 
DOI: 10.1159/000487778 & O 2018 The Author(s). Published by S. Karger AG, Basel \\
www.karger.com/cpb
\end{tabular} \\ Cao et al.: Ceritinib Sensitive Platelet Function}

is a powerful stimulator of platelet activation and arterial thrombosis [23]. An increase of $\left[\mathrm{Ca}^{2+}\right]_{\mathrm{i}}$ further triggers cell membrane scrambling with translocation of phosphatidylserine to the platelet surface $[22,38-40]$. The effect of ceritinib in platelets contrasts the effect of ceritinib in erythrocytes, where it enhances $\left[\mathrm{Ca}^{2+}\right]_{i}$, an effect contributing to the stimulation of eryptosis, the suicidal erythrocyte death [17]. The signaling accounting for stimulation of $\mathrm{Ca}^{2+}$ entry in erythrocytes and for inhibition of $\mathrm{Ca}^{2+}$ entry into blood platelets remains elusive. Ceritinib could be effective by inhibition of ALK [1-15]. The present observations do, however, not rule out involvement of mechanisms other than ALK.

The opposite effects of ceritinib in erythrocyte and platelets are reminiscent of opposing effects of cholestasis, bile acids and/or bilirubin on eryptosis and platelet activation [41-44]. Again, additional experimental effort is required to explore the putative involvement of ALK and/or further ceritinib sensitive signalling pathways.

Whatever signaling involved, phosphatidylserine exposing platelets foster stimulation of coagulation and thus impact on hemostasis [45]. Eventually phosphatidylserine exposing platelets are bound to and engulfed by macrophages [46]. In view of the inhibitory effect of ceritinib on platelet activation and apoptosis, it is tempting to speculate that the substance may counteract thrombosis. At least in theory ceritinib could further expand the platelet life span, which is a function of apoptosis [47].

In conclusion, ceritinib decreases $\left[\mathrm{Ca}^{2+}\right]_{\mathrm{i}}$ and, more importantly, blunts the stimulating effect of CRP on platelet $\left[\mathrm{Ca}^{2+}\right]_{\mathrm{i}}$, ROS abundance, P-selectin abundance, $\alpha_{\mathrm{IIb}} \beta_{3}$ integrin activity, cell membrane scrambling, cell shrinkage, caspase activity, and aggregation, and thus attenuates CRP-induced platelet activation and apoptosis.

\section{Acknowledgements}

We thank Lejla Subasic for meticulous preparation of the manuscript. This study was supported by the Deutsche Forschungsgemeinschaft and Open Access Publishing Fund of Tuebingen University, by the Klinische Forschergruppe [DFG-KFO 274] 'Platelets-Molecular Mechanisms and Translational Implications', as well as the Tuebingen Platelet Investigative Consortium (TuePIC). Work of R.B. is supported by the Institutional Strategy of the University of Tübingen (Deutsche Forschungsgemeinschaft, ZUK63).

\section{Disclosure Statement}

The authors of this manuscript state that they have no conflicts of interest to declare.

\section{References}

1 Cooper MR, Chim H, Chan H, Durand C: Ceritinib: a new tyrosine kinase inhibitor for non-small-cell lung cancer. Ann Pharmacother 2015;49:107-112.

Dhillon S, Clark M: Ceritinib: first global approval. Drugs 2014;74:1285-1291.

El-Osta H, Shackelford R: Personalized treatment options for ALK-positive metastatic non-small-cell lung cancer: potential role for Ceritinib. Pharmgenomics Pers Med 2015;8:145-154.

4 Giroux Leprieur E, Fallet V, Wislez M: [Modalities of use of ceritinib (Zykadia), a 2nd generation ALK inhibitor, in advanced stage non-small cell lung cancer]. Bull Cancer 2015;102:1053-1057.

5 Kaczmar J, Mehra R: The efficacy of ceritinib in patients with ALK-positive non-small cell lung cancer. Ther Adv Respir Dis 2015;9:236-241.

6 Kanaan Z, Kloecker GH, Paintal A, Perez CA: Novel targeted therapies for resistant ALK-rearranged nonsmall-cell lung cancer: ceritinib and beyond. Onco Targets Ther 2015;8:885-892. 


\section{Cellular Physiology Cell Physiol Biochem 2018;45:1707-1716

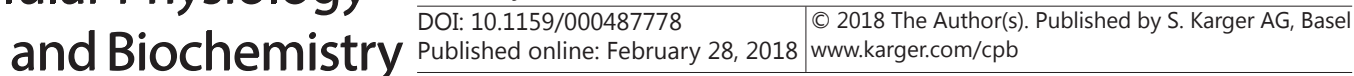

7 Katayama R, Sakashita T, Yanagitani N, Ninomiya H, Horiike A, Friboulet L, Gainor JF, Motoi N, Dobashi A, Sakata S, Tambo Y, Kitazono S, Sato S, Koike S, John Iafrate A, Mino-Kenudson M, Ishikawa Y, Shaw AT, Engelman JA, Takeuchi K, Nishio M, Fujita N: P-glycoprotein Mediates Ceritinib Resistance in Anaplastic Lymphoma Kinase-rearranged Non-small Cell Lung Cancer. EBioMedicine 2016;3:54-66.

-8 Khozin S, Blumenthal GM, Zhang L, Tang S, Brower M, Fox E, Helms W, Leong R, Song P, Pan Y, Liu Q, Zhao P, Zhao H, Lu D, Tang Z, Al Hakim A, Boyd K, Keegan P, Justice R, Pazdur R: FDA approval: ceritinib for the treatment of metastatic anaplastic lymphoma kinase-positive non-small cell lung cancer. Clin Cancer Res 2015;21:2436-2439.

-9 Landi L, Cappuzzo F: Ceritinib for the treatment of non-small cell lung cancer. Drugs Today (Barc) 2014;50:465-473.

10 Li S, Qi X, Huang Y, Liu D, Zhou F, Zhou C: Ceritinib (LDK378): a potent alternative to crizotinib for ALKrearranged non-small-cell lung cancer. Clin Lung Cancer 2015;16:86-91.

-11 Massarelli E, Papadimitrakopoulou V: Ceritinib for the treatment of late-stage (metastatic) non-small cell lung cancer. Clin Cancer Res 2015;21:670-674.

12 Nishio M, Murakami H, Horiike A, Takahashi T, Hirai F, Suenaga N, Tajima T, Tokushige K, Ishii M, Boral A, Robson M, Seto T: Phase I Study of Ceritinib (LDK378) in Japanese Patients with Advanced, Anaplastic Lymphoma Kinase-Rearranged Non-Small-Cell Lung Cancer or Other Tumors. J Thorac Oncol 2015;10:1058-1066.

13 Nix NM, Brown KS: Ceritinib for ALK-Rearrangement-Positive Non-Small Cell Lung Cancer. J Adv Pract Oncol 2015;6:156-160.

14 Rothschild SI: New treatment options for ALK+ advanced non-small-cell lung cancer: critical appraisal of ceritinib. Ther Clin Risk Manag 2016;12:735-741.

15 Vansteenkiste JF: Ceritinib for treatment of ALK-rearranged advanced non-small-cell lung cancer. Future Oncol 2014;10:1925-1939.

-16 Kang CH, Kim EY, Kim HR, Lee CO, Lee HK, Jeong HG, Choi SU, Yun CS, Hwang JY, Lee JY, Son YH, Ahn S, Lee BH, Jung H, Park CH: Minor modifications to ceritinib enhance anti-tumor activity in EML4-ALK positive cancer. Cancer Lett 2016;374:272-278.

17 Al Mamun Bhuyan A, Signoretto E, Bissinger R, Lang F: Stimulation of Suicidal Erythrocyte Death by Ceritinib-Treatment of Human Erythrocytes. Cell Physiol Biochem 2016;40:1129-1140.

18 Gyulkhandanyan AV, Mutlu A, Freedman J, Leytin V: Markers of platelet apoptosis: methodology and applications. J Thromb Thrombolysis 2012;33:397-411.

19 Lebois M, Josefsson EC: Regulation of platelet lifespan by apoptosis. Platelets 2016;27:497-504.

20 Borst O, Schmidt EM, Munzer P, Schonberger T, Towhid ST, Elvers M, Leibrock C, Schmid E, Eylenstein A, Kuhl D, May AE, Gawaz M, Lang F: The serum- and glucocorticoid-inducible kinase 1 (SGK1) influences platelet calcium signaling and function by regulation of Orai1 expression in megakaryocytes. Blood 2012;119:251-261.

21 Gawaz M: Role of platelets in coronary thrombosis and reperfusion of ischemic myocardium. Cardiovasc Res 2004;61:498-511.

-22 Borst O, Munzer P, Gatidis S, Schmidt EM, Schonberger T, Schmid E, Towhid ST, Stellos K, Seizer P, May $\mathrm{AE}$, Lang F, Gawaz M: The inflammatory chemokine CXC motif ligand 16 triggers platelet activation and adhesion via CXC motif receptor 6-dependent phosphatidylinositide 3-kinase/Akt signaling. Circ Res 2012;111:1297-1307.

-23 Bergmeier W, Stefanini L: Novel molecules in calcium signaling in platelets. J Thromb Haemost 2009;7 Suppl 1:187-190.

24 Varga-Szabo D, Braun A, Nieswandt B: Calcium signaling in platelets. J Thromb Haemost 2009;7:10571066.

25 Braun A, Varga-Szabo D, Kleinschnitz C, Pleines I, Bender M, Austinat M, Bosl M, Stoll G, Nieswandt B: Orai1 (CRACM1) is the platelet SOC channel and essential for pathological thrombus formation. Blood 2009;113:2056-2063.

26 Varga-Szabo D, Braun A, Nieswandt B: STIM and Orai in platelet function. Cell Calcium 2011;50:270-278.

27 Wang Y, Deng X, Gill DL: Calcium signaling by STIM and Orai: intimate coupling details revealed. Sci Signal 2010;3:pe42. 


\section{Cellular Physiology Cell Physiol Biochem 2018;45:1707-1716

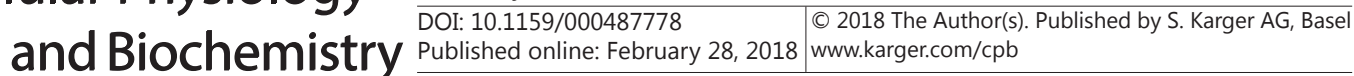

28 Liu G, Liu G, Chen H, Borst O, Gawaz M, Vortkamp A, Schreiber R, Kunzelmann K, Lang F: Involvement of Ca2+ Activated Cl- Channel Ano6 in Platelet Activation and Apoptosis. Cell Physiol Biochem 2015;37:19341944.

29 Honisch S, Gu S, Vom Hagen JM, Alkahtani S, Al Kahtane AA, Tsapara A, Hermann A, Storch A, Schols L, Lang F, Stournaras C: Chorein Sensitive Arrangement of Cytoskeletal Architecture. Cell Physiol Biochem 2015;37:399-408.

-30 Liu G, Liu G, Alzoubi K, Chatterjee M, Walker B, Munzer P, Luo D, Umbach AT, Elvira B, Chen H, Voelkl J, Foller M, Mak TW, Borst O, Gawaz M, Lang F: CD44 sensitivity of platelet activation, membrane scrambling and adhesion under high arterial shear rates. Thromb Haemost 2015;115:

-31 Liu G, Cao H, Liu G, Heinzmann D, Chen H, Umbach AT, Gawaz M, Lang F: Effect of Lysosomotropic Polyamineoxidase Inhibitor MDL-72527 on Platelet Activation. Cell Physiol Biochem 2016;38:1695-1702.

-32 Liu G, Liu G, Chatterjee M, Umbach AT, Chen H, Gawaz M, Lang F: Influence of gamma-Secretase Inhibitor 24-Diamino-5-Phenylthiazole DAPT on Platelet Activation. Cell Physiol Biochem 2016;38:726-736.

-33 Liu G, Liu G, Chen H, Alzoubi K, Umbach AT, Gawaz M, Stournaras C, Lang F: Rapid Upregulation of Orai1 Abundance in the Plasma Membrane of Platelets Following Activation with Thrombin and Collagen Related Peptide. Cell Physiol Biochem 2015;37:1759-1766.

34 Dong J, Lin J, Wang B, He S, Wu C, Kushwaha KK, Mohabeer N, Su Y, Fang H, Huang K, Li D: Inflammatory cytokine TSLP stimulates platelet secretion and potentiates platelet aggregation via a TSLPR-dependent PI3K/Akt signaling pathway. Cell Physiol Biochem 2015;35:160-174.

-35 Pyo JS, Cho WJ: Mean Platelet Volume, Platelet Distribution Width, and Platelet Count in Varicocele: A Systematic Review and Meta-Analysis. Cell Physiol Biochem 2016;38:2239-2246.

-36 De Cuyper IM, Meinders M, van de Vijver E, de Korte D, Porcelijn L, de Haas M, Eble JA, Seeger K, Rutella S, Pagliara D, Kuijpers TW, Verhoeven AJ, van den Berg TK, Gutierrez L: A novel flow cytometry-based platelet aggregation assay. Blood 2013;121:e70-80.

-37 Lang F, Munzer P, Gawaz M, Borst O: Regulation of STIM1/Orai1-dependent Ca2+ signalling in platelets. Thromb Haemost 2013;110:925-930.

-38 Harper MT, Poole AW: Store-operated calcium entry and non-capacitative calcium entry have distinct roles in thrombin-induced calcium signalling in human platelets. Cell Calcium 2011;50:351-358.

-39 Mahaut-Smith MP: A role for platelet TRPC channels in the Ca2+ response that induces procoagulant activity. Sci Signal 2013;6:pe23.

40 Mushtaq M, Nam TS, Kim UH: Critical role for CD38-mediated Ca2+ signaling in thrombin-induced procoagulant activity of mouse platelets and hemostasis. J Biol Chem 2011;286:12952-12958.

41 Gowert NS, Klier M, Reich M, Reusswig F, Donner L, Keitel V, Haussinger D, Elvers M: Defective Platelet Activation and Bleeding Complications upon Cholestasis in Mice. Cell Physiol Biochem 2017;41:2133-2149.

42 Kile BT: The role of the intrinsic apoptosis pathway in platelet life and death. J Thromb Haemost 2009;7 Suppl 1:214-217.

43 Lang E, Gatidis S, Freise NF, Bock H, Kubitz R, Lauermann C, Orth HM, Klindt C, Schuier M, Keitel V, Reich M, Liu G, Schmidt S, Xu HC, Qadri SM, Herebian D, Pandyra AA, Mayatepek E, Gulbins E, Lang F, Haussinger D, Lang KS, Foller M, Lang PA: Conjugated bilirubin triggers anemia by inducing erythrocyte death. Hepatology 2015;61:275-284.

44 Shiao YJ, Chen JC, Wang CN, Wang CT: The mode of action of primary bile salts on human platelets. Biochim Biophys Acta 1993;1146:282-293.

45 Lhermusier T, Chap H, Payrastre B: Platelet membrane phospholipid asymmetry: from the characterization of a scramblase activity to the identification of an essential protein mutated in Scott syndrome. J Thromb Haemost 2011;9:1883-1891.

46 Badlou BA, Wu YP, Smid WM, Akkerman JW: Platelet binding and phagocytosis by macrophages. Transfusion 2006;46:1432-1443.

47 Lang E, Pozdeev VI, Gatidis S, Qadri SM, Haussinger D, Kubitz R, Herebian D, Mayatepek E, Lang F, Lang KS, Lang PA: Bile Acid-Induced Suicidal Erythrocyte Death. Cell Physiol Biochem 2016;38:1500-1509. 